原著

\title{
インフルエンザ $\mathrm{A} 及 ひ ゙ \mathrm{~B}$ 型ウイルスノイラ ミニダーゼ間の酵素学的な差異について
}

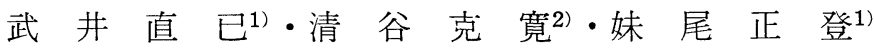 \\ 松 尾 吉 恭2)
}

（受付：昭和60年10月 24 日）

\begin{abstract}
総括

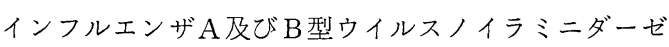
(NA) 間の酵素学的な差異を明らかにすることを目的 として, A, B両型ウイルス各10株ずつについて, フェ チュインを基質として用いる呈色比色法と, 4-メチルウ ンベリフェリルーN-アセチルー $\alpha-\mathrm{D}$-ノイラミニド (4$\mathrm{MU}$-ノイラミニド）を基質として用いる蛍光比色法と によって，そのNA活性を測定した。

蛍光比色法では, A型ウィルスの NAは, 10m Mエチ レンジアミン四酢酸（E D T A ）により著明に抑制され たのに対して，B型ウイルスのそれは全く抑制されなか った.
\end{abstract}

$\mathrm{B}$ 型ウイルス $\mathrm{NA}$ の加水分解活性の呈色比色法/蛍光 比色法の比は, A 型ウイルスのそれに比して著明に高か った。また， B 型ウイルスの NA ミニン酸（NANA）による競合阻害の程度も，A型ウ イルスの NAに拈けるよりあ弱く, A, B両型ウイルス N A間の基質特異性に差のあることが示唆された。

$\mathrm{A}, \mathrm{B}$ 両型インフルエンザウイルスNAについて，4$\mathrm{MU}$-ノイラミニドという低分子の合成基質を用いる蛍 光比色法を応用することで, 兩者が異なる態度を示した

Enzymologically Different Characteristics between Influenza A and B Virus Neuraminidases.

Naomi TAKEI ${ }^{1}$, Katsuhiro KIYOTANI ${ }^{2}$ ) Masato SENOO1), and Yoshiyasu MATSUO ${ }^{2}$ (Hiroshima Prefectural Instiute of Public Health') and Department of Bacteriology, Hiroshima University School of Medicine ${ }^{2)}$ )

1）広島県衛生研究所生物学部

2) 広島大学医学部細菌学教室

于734 広島市南区宇品神田 1-5-70
ことは極めて興味あることと思われる。

\section{序文}

NA (N-acetylneuraminate glycohydrolase, EC 3 . 2. 1. 18) は, オルソミクソ及びパラミクソウイルスの 他, 細菌, 原虫及び脊椎動物細胞や発育鶏卵の浆尿膜細 胞などにも存在が確認されており, それぞれ酵素学上の 特徴をあつてとが知られている ${ }^{1,8,9,16,18)}$.

インフルエンザウイルスの NAについても, その至適 $\mathrm{pH}$ や基質特異性にはウイルス株間でかなり差のあるこ とが知られている ${ }^{2,6,7,9,14,16)}$. しかし, $\mathrm{Ca}^{2+}$ イオン依存 性という点については，これまで A， B両型ウイルス間 には違いはなく, ともにEDT A 存在下で著明にその活 性が抑制されるとされてきた ${ }^{5,6,16,20)}$.

先に我々は, Myers ら (1980) ${ }^{15)}$ にって合成された 4-MUーノイラミニドを基質として用いる蛍光比色法 ${ }^{11)}$ を応用し, インフルエンザウイルスのNA活性を測定し, そのなかで B / 神奈川 $/ 3 / 76$ 株のNAが E D T A によ って全く抑制されず, A / 愛知 $/ 2 / 68$ 及び A U USSR /92/77両株のそれとは明らかに異なる特徵をむつとと を報告した ${ }^{12)}$. 次いで, 1940年から1984年の間に世界各 地で分離された 26 株のB型ウィルスについて検討し, 先 に示された ${ }^{12)} \mathrm{B} /$ 神奈川 $/ 3 / 76$ 株の NAのもつ酵素活 性の特徵が, B型ウイルス全般に共通してみられる性質 であることを明らかにした

そこで今回は，てれまでの知見をさらに発展させるた め, A 型ウイルス株も含めて検討したので報告する.

\section{材料と方法}

1. 供試ウイルス株

A， B両型インフルエンザウイルス各 10 株を供試した. この内, 広島県下の流行例より分離された 2 株の B 型株 を除く各ウイルス株は, 国立予防衛生研究所, 武内安恵 
Table 1. Hemagglutination titer and neuraminidase activity of various influenza viruses

\begin{tabular}{|c|c|c|c|c|}
\hline \multirow{2}{*}{ Influenza virus } & \multirow{2}{*}{$\begin{array}{l}\text { HA } \\
\text { titer }\end{array}$} & \multicolumn{3}{|c|}{ Neuaminidase activity ${ }^{1)}$} \\
\hline & & Fluorometry & Colorimetry & Ratio \\
\hline \multicolumn{5}{|l|}{ Type A (H1N1) } \\
\hline $\mathrm{A} / \mathrm{PR} / 8 / 34$ & 512 & 25,900 & 70,800 & 2.7 \\
\hline $\mathrm{A} / \mathrm{FM} / 1 / 47$ & 1,024 & 45,500 & 110,000 & 2.4 \\
\hline A/Omachi/1/53 & 512 & 5,900 & 11,460 & 1.9 \\
\hline A/USSR/92/77 & 1,024 & 62,800 & 56,300 & 0.9 \\
\hline \multicolumn{5}{|l|}{ Type A (H2N2) } \\
\hline A/Adachi $/ 2 / 57$ & 512 & 142,000 & 628,800 & 4.4 \\
\hline A/Singapore/1/57 & 256 & 127,000 & 691,200 & 5.4 \\
\hline \multicolumn{5}{|l|}{ Type A (H3N2) } \\
\hline A/Aichi/2/68 & 512 & 71,780 & 380,800 & 5.3 \\
\hline A/Portchalmers/1/72 & 1,024 & 131,000 & 337,600 & 2.9 \\
\hline A/Victoria/3/75 & 512 & 92,400 & 320,000 & 3.5 \\
\hline A/Bangkok/1/79 & 512 & 32,100 & 56,400 & 1.8 \\
\hline \multicolumn{5}{|l|}{ Type B } \\
\hline $\mathrm{B} /$ Lee $/ 40$ & 256 & 10,060 & 109,200 & 10.9 \\
\hline B/Setagaya/3/56 & 1,024 & 9,060 & 132,880 & 14.7 \\
\hline B/Taiwan/4/62 & 512 & 7,600 & 129,440 & 17.0 \\
\hline $\mathrm{B} /$ Tokyo/7/66 & 256 & 4,860 & 91,400 & 18.8 \\
\hline $\mathrm{B} /$ Osaka/2/70 & 1,024 & 8,800 & 141,280 & 16.1 \\
\hline $\mathrm{B} / \mathrm{Gifu} / 2 / 73$ & 256 & 10,360 & 162,880 & 15.7 \\
\hline $\mathrm{B} /$ Kanagawa/3/76 & 256 & 7,700 & 119,840 & 15.6 \\
\hline $\mathrm{B} /$ Singapore/222/79 & 512 & 7,300 & 132,400 & 18.1 \\
\hline B/Hiroshima/3/83 & 256 & 4,786 & 89,600 & 18.7 \\
\hline B/Hiroshima/2/85 & 128 & 2,220 & 42,960 & 19. 4 \\
\hline \multicolumn{5}{|c|}{ Partially purified virus preparation ${ }^{2)}$} \\
\hline B/Lee/40 & 64 & 4,180 & 40,400 & 9.7 \\
\hline B/Taiwan/4/62 & 1,024 & 6,460 & 88,960 & 13. 8 \\
\hline $\mathrm{B} / \mathrm{Gifu} / 2 / 73$ & 2,560 & 136,600 & $1,180,000$ & 8.6 \\
\hline $\mathrm{B} /$ Kanagawa $/ 3 / 76$ & 5,120 & 283,000 & $2,822,247$ & 10.0 \\
\hline $\mathrm{B} /$ Singapore/222/79 & 5,120 & 180,000 & $2,040,000$ & 11.3 \\
\hline
\end{tabular}

1) Neuraminidase activity was measured fluorometrically using 4-MU-N-Ac- $\alpha-\mathrm{D}$-neuraminide and colorimetrically using fetuin as substrate. Enzyme activity was expressed as pmol/hr/100 $\mu 1$ of sample and the ratio was calculated as enzyme activity measured by colorimetric assay/fluorometric assay.

2) Virus preparations were grown in MDCK cells and partially purified by differential centrifugation.

博士より分与を受けた。 これらのウイルス株は全て再度 発育鶏卵に接種し, その感染䍝尿液をウイルス液として 使用した。 また，一部の B 型株については，MDCK細 胞で培養したウイルス液を分別遠心にて部分精製したも のむ用いた。

\section{N A 活性の測定}

$\mathrm{NA}$ 活性の測定は 2 種類の異なる測定系で行った。 呈 色比色法はフェチュイン (Type III, Sigma Chemicals,
USA）を基質として Aymard-Henry ら (1973) ${ }^{3)}$ の方 法に準じて行い, 蛍光比色法は 4-MU-ノイラミニド (Koch Light Laboratories, England) を基質として既 に報告した方法 ${ }^{11)}$ に準じて行った，反応時間は前者では $37^{\circ} \mathrm{C} 18$ 時間, 後者では 150 分とし各々遊離してきた $\mathrm{NA}$ NA及び 4-MU を定量し，活性は用いたウイルス液 $100 \mu l$ 当り 1 時間値で示した.

各 NA 活性に及ぼす EDTA 及び NANA の影響の 
Table 2. Effect of EDTA and N-acetylneuraminic acid on influenza viral neuraminidase activity

\begin{tabular}{|c|c|c|c|}
\hline \multirow[b]{3}{*}{ Influenza virus } & \multicolumn{3}{|c|}{$\%$ Activity with } \\
\hline & \multicolumn{2}{|c|}{$10 \mathrm{mM} \mathrm{EDTA}^{12}$} & \multirow[b]{2}{*}{$25 \mathrm{mM} \mathrm{NANA}^{2)}$} \\
\hline & Fluorometry & Colorimetry & \\
\hline \multicolumn{4}{|l|}{ Type A (H1N1) } \\
\hline $\mathrm{A} / \mathrm{PR} / 8 / 34$ & 15 & 7 & 29 \\
\hline $\mathrm{A} / \mathrm{FM} / 1 / 47$ & 22 & 6 & 47 \\
\hline A/Omochi/1/53 & 5 & 7 & 25 \\
\hline A/USSR/92/77 & 10 & 12 & 23 \\
\hline \multicolumn{4}{|l|}{ Type A (H2N2) } \\
\hline A/Adachi/2/57 & 24 & 29 & 38 \\
\hline A/Singapore/1/57 & 27 & 29 & 36 \\
\hline \multicolumn{4}{|l|}{ Type A (H3N2) } \\
\hline A/Aichi/2/68 & 48 & 79 & 22 \\
\hline A/Portchalmers/1/72 & 45 & 26 & 27 \\
\hline $\mathrm{A} /$ Victoria $/ 3 / 75$ & 20 & 9 & 25 \\
\hline A/Bangkok/1/79 & 3 & 5 & 38 \\
\hline \multicolumn{4}{|l|}{ Type B } \\
\hline B/Lee/40 & 120 & 13 & 83 \\
\hline B/Setagaya/3/56 & 130 & 50 & 81 \\
\hline B/Taiwan/4/62 & 149 & 53 & 86 \\
\hline B/Tokyo/7/66 & 132 & 47 & 73 \\
\hline B/Osaka/2/70 & 127 & 49 & 83 \\
\hline $\mathrm{B} / \mathrm{Gifu} / 2 / 73$ & 124 & 51 & 82 \\
\hline $\mathrm{B} /$ Kanagawa $/ 3 / 76$ & 118 & 50 & 87 \\
\hline $\mathrm{B} /$ Singapore/222/79 & 116 & 48 & 73 \\
\hline B/Hiroshima/3/83 & 116 & 46 & 96 \\
\hline B/Hiroshima/2/85 & 103 & 55 & 75 \\
\hline \multicolumn{4}{|c|}{ Partially purified virus preparation } \\
\hline $\mathrm{B} /$ Lee $/ 40$ & 117 & 2 & 90 \\
\hline B/Taiwan/4/62 & 137 & 56 & 71 \\
\hline $\mathrm{B} / \mathrm{Gifu} / 2 / 73$ & 112 & 41 & 75 \\
\hline $\mathrm{B} /$ Kanagawa $/ 3 / 76$ & 110 & 51 & 88 \\
\hline B/Singapore/222/79 & 118 & 53 & 88 \\
\hline
\end{tabular}

1) Percent activity was calculated as follows: (enzyme activity with $10 \mathrm{mM} \mathrm{EDTA/without} \mathrm{EDTA)}$ $\mathrm{x} 100$.

2) Percent activity measured fluorometrically using 4-MU-N-Ac- $\alpha-\mathrm{D}$-neuraminide as a substrate was calculated as follows: (enzyme activity with $25 \mathrm{mM}$ NANA/without NANA).

測定に当っては，各ウイルス液の NA 活性をそれぞれ $10 \mathrm{n} \mathrm{mol} /$ 時間 $/ 100 \mu l$ (呈色比色法) 及び $400 \mathrm{pmol} /$ 時間 $/ 100 \mu l$ (蛍光比色法) に調製し, $2 \mathrm{mM} \mathrm{CaCl}_{2}$ 加反 応液に EDTA $10 \mathrm{mM}$ あるいは NANA (Type VI, Sigma Chemicals, USA) $25 \mathrm{mM}$ を添加して測定した.

\section{成 績}

1. 蛍光比色, 呈色比色両測定法に打ける $\mathrm{NA}$ 活性 両測定法に打ける各ウイルス液のNA活性をまとめて
Table 1 に示した，成績は，個々の活性值ととあにそれ らの両測定法における活性の比（呈色比色法の活性／蛍 光比色法の活性）をとって比較する形で記載した.

A 型ウイルスでは, 呈色比色法の活性が蛍光比色法の それの $2 \sim 5$ 倍強い值 (平均 3.1 倍) であった. これに 対して, B型ウイルスでは呈色比色法のそれが蛍光比色 法のそれより 10～20倍も強く，両測定法の活性比の平均 は16.5であった。部分精製ウイルス液においてもほぼ同 様の傾向であった。 


\section{EDTA 及び NANA 添加の影響}

$10 \mathrm{mM}$ EDTA 添加の影響を呈色比色, 蛍光比色両測 定法で, また $25 \mathrm{mM}$ NANA 添加による影響を蛍光比 色法で測定し, 成績を Table 2 に示した.

A型ウイルスに抢いては, ウイルス株間で程度の差は あるものの EDTA 添加により両測定系とあにその活性 は強く抑制され，両測定法に扔ける活性抑制率の平均は それぞれ 78.1\%及び 79.1\%であった。しかし B型ウイ ルスでは, 呈色比色法では $\mathrm{A}$ 型ウイルスのそ机と比較す るとかなり弱いものの平均 $53.8 \%$ の抑制が認められたが, 蛍光比色法では全く抑制はみられなかった。

一方, NANAによる競合阻害の程度は, A型ウイル スでは平均69.0\%と強く㧕制されたが，B型株の活性抑 制の程度は平均 $18.1 \%$ 之 A 型ウィルスのそれと比較して

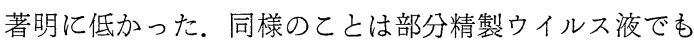
認められた。

\section{考察}

以上の成績から，まず両測定系における供試 $\mathrm{A}, \mathrm{B}$ 両 型ウイルス間の NA 活性は，フェチュインを基質とする 場合と 4-MU-ノイラミニドを基質とする場合とではそ の活性に明らかに差が認められる (Table 1). 勿論呈色 比色法と蛍光比色法とは異なった測定系であり, 用いる 基質も異なるが ${ }^{15,17)}$ ，それぞれの単位当りの活性値を指 標とするととによって両者は比較しうるものと思われる. したがって, 乙の加水分解の差は $\mathrm{A}, \mathrm{B}$ 両型ウィルス $\mathrm{N}$ Aのそれぞれの基質に対する加水分解の程度をそのまま 反映しているあの之解される.

一般にはウィルス, 細菌あるいはそれ以外のあのに由 来するはNAは，N-アセチル及びN-グリコリルの 2 種 のノィラミニン酸の内NANAをより効果的に水解する とされているが7)， その逆の場合のあることも知られて いる77. フェチュインは上記 2 種のノイラミン酸を含む が，そのフェチュインに対してB型ウイルスのNAがA 型に比べて強い加水分解活性を示したととは，NANA による競合阻害にも，A，B両型ウイルス間で差の認め られる (Table 2) ことと併せて興味深いが，これらの メカニズムについては現段階では言及できない.

次に，インフルエンザウイルス NAのEDTA に対す る態度については，初期において主としてA型ウイルス について行われた仕事 ${ }^{5,19)}$ を除いてはその後系統的に検 討された報告は少ない．その中にあってもEDTA 非感 受性のNAについての報告はない，乙の点に関する最近

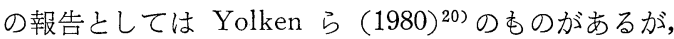
彼らは蛍光比色法を用い, $10 \mathrm{mM}$ EDTA により A, B 両型インフルエンザウイルスの NAは共に著明に抑制え
れたと報告している. 我々はこの点に関して, 4-MUノイラミニドを基質とする蛍光比色法では， B 型ウィル スの NA 活性が $10 \mathrm{mM}$ EDTA で全く㧕制されないこ とをみたが ${ }^{12,13)}$, 乙の違いの理由は現在のところ不明で ある。一方, A 型ウイルスの NA 活性は, $10 \mathrm{mM}$ EDTA 添加によって呈色, 蛍光の両測定系とも著明に抑制 され，乙の点ではこれまでの諸報告 $5,6,16,19)$ 之一致した。

これとは別に，インフルエンザウイルスNAの温度に 対する安定性についての $\mathrm{Ca}^{2+}$ イオンの役割について, Baker and Gandhi $(1976)^{4)}$ は $\mathrm{Ca}^{2+}$ イオン非存在下で は， $37^{\circ} \mathrm{C}$ に扔いても活性低下のみられることを指摘して いる。しかし，今回我々がみた両測定法に拈ける B 型ウ イルス $\mathrm{NA}$ の $\mathrm{Ca}^{2+}$ イオン依存性の差は，乙れまでの 測定系の検討から両測定法の反応時間の差によるNAの 安定性に基づくものとは考元られない.

なお，乙れまで述べた $\mathrm{A}, \mathrm{B}$ 両型インフルエンザウィ ルス NAの酵素学的特徵が, 宿主細胞由来の因子や, 混 入細菌由来のものでないととは, MDCK 細胞由来の B 型ウイルスの部分精製ウイルス液を用いた成績からチェ ックされたものと考えている。

以上, 今回の成績は $\mathrm{A}, \mathrm{B}$ 両型インフルエンザウイル ス $\mathrm{NA}$ 間には，その基質特異性及び $\mathrm{Ca}^{2+}$ イオン依存性 に扔いて全く同一ではなく，低分子単純基質を用いるこ とによって表現されうるような違いのあることを示唆す るあのと考えられるが，なお今後の検討が必要である.

\section{謝辞}

稿を終るにあたり，インフルエンザウイルス株を分与 して下さった国立予防衛生研究所の武内安恵博士に深謝 いたします。

\section{文献}

1) Ada, G. L. and Lind, P. E. (1960). Neuraminidase in the cholioallantois of the chick embryo. Nature 227: 1169-1171.

2) Aoyagi, T., Komiyama, T., Nerome, K., Takeuchi, T. and Umezawa, H. (1975). Characterization of myxovirus sialidase. Experientia 31 : 896-898.

3) Aymard-Henry, M., Coleman, M. T., Dowdle, W. R., Laver, W. G., Schild, G. C. and Webster, R. G. (1973). Influenza virus neuraminidase and neuraminidase-inhibition test procedures. Bull. WHO 48: 199-202.

4) Baker, N. J. and Gandhi, S. S. (1976). Effect of $\mathrm{Ca}^{2+}$ on the stability of influenza virus neuraminidase. Arch. Virol. 52 : 7-18.

5) Boschman, T. A. C. and Jacobs, J. (1965). The 
influence of ethylenediaminetetraacetate on various neuraminidases. Biochemiche Zeitschrift 342 : 532-541.

6) Bucher, D. and Palese, P. (1975). The biologically active proteins of influenza virus : Neuraminidase. In: E. D. Kilbourne (Ed.), The influenza virus and influenza, p. 83-123. Academic Press, New York San Francisco London.

7) Corfield, A. P., Veh, R. W., Wember, M., Michalski, J-C and Schauer, R. (1981). The release of $\mathrm{N}$-acetyl-and $\mathrm{N}$-glycolylneuraminic acid from soluble complex carbohydrates by bacterial, viral and mammalian sialidases. Biochem. J. 197 : 293-299.

8) Drzeniek, R. (1972). Viral and bacterial neuraminidases. Curr. Top. Microbiol. Immunol. 59 : 35-74.

9) Gottschalk, A. and Drzeniek, R. (1972). Neuraminidase as a tool in structural analysis. In : A. Gottschalk (Ed.), Glycoprotein Part A, p. 381-402. Elsevier Publishing Co., Amsterdam.

10) Graham, E. R. B. (1966). Serum glycoproteins. In: A. Gottschalk (Ed.), Glycoproteins, p. 356361. Elsevier Pubulising Co., Amsterdam.

11) Kiyotani, K., Takei, N. and Matsuo, Y. (1984). Fluorometric measurement of neuraminidase activity of influenza viruses. Hiroshima J. Med. Sci. 33 : 287-292.

12）清谷克寛 (1984). インフルエンザウイルス B/神奈 川 $3 / 76$ 株のカルシウム非依存性ノイラミニダーゼ 活性. 医学々生物学. 109: 83-86.

13) Kiyotani, K., Takei, N. and Matsuo, Y.(1985). Enzymological heterogeneity of influenza $B$ virus neuraminidase demonstrated by the fluorometric assay method. Zbl. Bakt. Hyg. A 260 : 273-285.

14) Lin, W., Oishi, K. and Aida, K. (1977). Specific inhibition of viral neuraminidases by an inhibitor, Neuraminin, produced by Streptomyces sp. Virology 78: 108-114.

15) Myers, R. W., Lee, R. T., Lee, Y. C., Thomas, G. H., Reynolds, L. W. and Uchida, Y.(1980). The synthesis of 4-methylumbelliferyl- $\alpha$-ketoside of $\mathrm{N}$-acetylneuraminic acid and its use in a fluorometric assay for neuraminidase. Anal. Biochem. 101 : 166-174.

16) Rafelson, M. E., Jr. (1963). The neuraminidases and their action on glycoproteins and other sialic acid-containing compounds. Exposes Ann. Biochem. Med. 24: 121-132.

17) Spiro, R. (1960). Studies on fetuin, a glycoproteins of fetal serum. I. Isolation, chemical composition and physicochemical properties. J. Biol. Chem. 235 : 2860-2869.

18) Warren, L. and Spearing, C. W. (1960). Mammalian sialidase (Neuraminidase). Biochem. Biophys. Res. Commun. 3: 489-492.
19) Wilson, V. W., Jr. and Rafelson, M. E., Jr. (1967). Studies on the neuraminidases of influenza virus. III. Stimulation of activity by bivalent cations. Biochim. Biophys. Acta 146: 160166.

20) Yolken, R. H., Torsch, V. M., Berg, R., Murphy, B. R. and Lee, Y. C. (1980). Fluorometric assay for measurement of viral neuraminidaseApplication to the rapid detection of influenza virus in nasal wash specimens. J. Infect. Dis. 142 : 516-523.

Enzymologically Different Characteristics between Influenza A and B Virus Neuraminidases

Naomi TAKEI ${ }^{1)}$, Katsuhiro KIYOTANI ${ }^{2)}$, Masato SENOO $^{1)}$, and Yoshiyasu MATSUO ${ }^{2}$

1) Hiroshima Prefectural Institute of Public Health, 1-5-70, Ujina Kanda, Minami-ku, Hiroshima 734, Japan.

2) Department of Bacteriology, Hiroshima University School of Medicine, 1-2-3, Kasumi, Minami-ku, Hiroshima 734, Japan.

Neuraminidase (NA) activity of 10 strains of influenza $A$ and 10 strains of influenza $B$ virus was determined by fluorometric and colorimetric assays using 4-methylumbelliferyl (4-MU)-N-Ac- $\alpha-\mathrm{D}$-neuraminide and fetuin as the substrate, respectively.

The ratio of NA activity measured by colorimetric assay to that measured by fluorometric assay was significantly higher with influenza $B$ virus than with influenza $A$ virus. When measured by fluorometric assay, NA activity of influenza $A$ virus was strongly inhibited by etylenediaminetetraacetate, while that of influenza $B$ virus was not. Influenza $B$ virus NA was also significantly less susceptible to competitive inhibition by $\mathrm{N}$-acetylneuraminic acid than influenza A virus NA, suggesting the different substrate specificity of the two NAs.

It is worth to note that such an enzymological heterogeneity between influenza $A$ and $B$ virus NAs is demonstrated only by the use of a low molecular weight synthetic substrate, $4-\mathrm{MU}-\mathrm{N}-\mathrm{Ac}-\alpha-\mathrm{D}-$ neuraminide and fluorometric assay. 